\title{
Shareholders Wealth Effects of Joint Venture Strategies*
}

\author{
Gertjan Schut \\ IBM Business Consulting Services, Netherlands \\ Ruud van Frederikslust \\ Erasmus University Rotterdam, Netherlands
}

\begin{abstract}
We investigate the shareholder wealth effects of 233 joint venture announcements of Dutch public companies in the period 1987 till 1998. The research shows that, on average, establishing joint ventures has a positive effect on the market value of Dutch companies. Using the strategic characteristics of joint ventures it is possible to explain and understand these wealth effects. Our research shows that the factors of strategic intention, the context in which the strategy is unfolded and the extent to which the company has control over the implementation strongly explains the extent to which a joint venture can create value (JEL G14, G15, G34, F23).
\end{abstract}

Keywords: joint venture strategy, event studies, shareholders value.

\section{Introduction}

We investigate shareholder wealth effects of 233 joint venture announcements by Dutch public companies in the period 1987 till 1998. The study focuses on joint ventures in which the consequences for the shareholders of the parent companies are central. Setting up a joint venture involves establishing a separate legal entity, with its own identity, liability and share capital. Most companies have experienced stagnation in their market value growth and cash flow margins up to three years before the establishment of a joint venture; e.g., Mohanram and Nanda (1998) and Bergman and Friedman (1977). This article addresses the joint venture strategy factors and how they have an impact

\footnotetext{
* We acknowledge comments on prior drafts by the anonymous referee and the editor Peter Theodossiou.
}

(Multinational Finance Journal, 2004, vol. 8, no. 3 \& 4, pp. 211-225)

(C) Multinational Finance Society, a nonprofit corporation. All rights reserved. DOI: $10.17578 / 8-3 / 4-3$ 


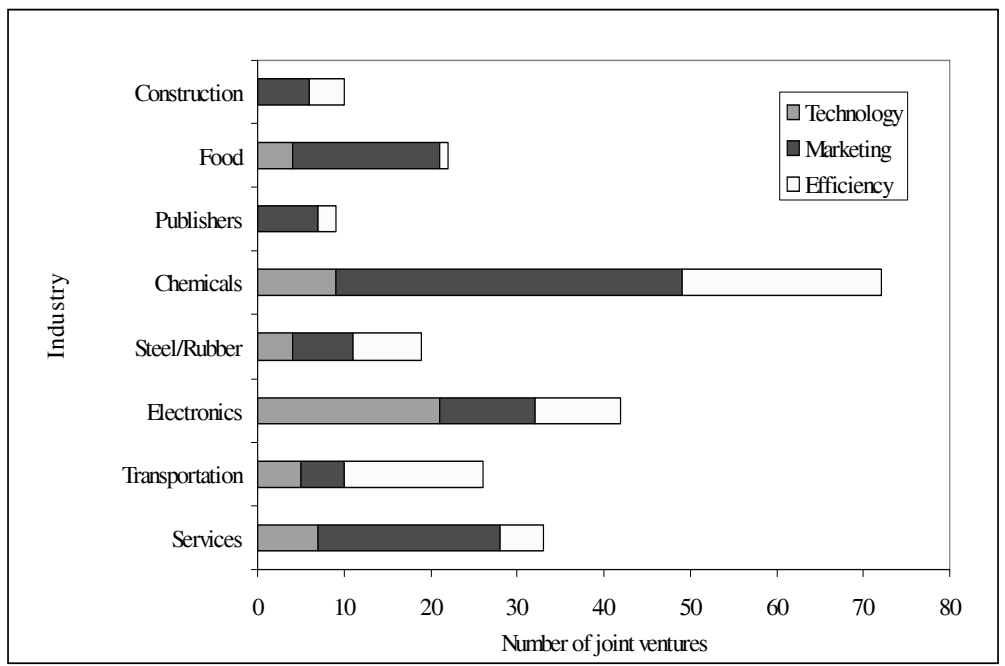

FIGURE 1.- Motive for the Joint Ventures by Sector

on the market value of parent companies. Section II outlines the sample survey and the applied research methodology. Section III presents the findings of the impact of the joint venture strategy on the market value of companies. ection IV presents the summary and conclusions.

\section{Data and Methodology}

\section{A. Data}

This research is based on the event study methodology developed by Fama et al. (1969). The initial announcement of a joint venture is defined as the 'event', while the market value is studied by examining the development of the share price. The announcements were found in the Dutch financial daily Het Financieele Dagblad. The study analyzed a sample of 233 non-financial joint ventures whose announcements met the following criteria:

The shares of at least one of the joint venture partners were being traded on the Amsterdam Stock Exchange at the time of the announcement. 
TABLE 1. Location of the Joint Venture and Nationality of the Partners

\begin{tabular}{lrrrrrrr}
\hline $\begin{array}{l}\text { Nationality } \\
\text { of Partner }\end{array}$ & Netherlands Europe & Nafta & $\begin{array}{l}\text { Japan \& } \\
\text { S. Korea }\end{array}$ & China & Other & Total \\
\hline $\begin{array}{l}\text { Dutch } \\
\text { European }\end{array}$ & 25 & 1 & 0 & 0 & 1 & 3 & 30 \\
Nafta & 11 & 27 & 0 & 0 & 2 & 5 & 44 \\
Japanese \& & 3 & 1 & 1 & 13 & 0 & 2 & 20 \\
$\begin{array}{l}\text { S. Korean } \\
\text { Chinese }\end{array}$ & 0 & 0 & 0 & 0 & 21 & 0 & 21 \\
Other & 0 & 1 & 1 & 0 & 1 & 32 & 35 \\
\hline Total & 49 & 39 & 13 & 13 & 25 & 44 & 183 \\
\hline
\end{tabular}

Note: When location could not be clearly identified, the joint venture was not included.

During the $(-20,20)$ days in which the market reaction was measured, no other relevant announcements regarding the companies participating in the alliance appeared in Het Financieele Dagblad.

The companies involved were not financial institutions ${ }^{1}$.Forty-eight Dutch companies, that is, approximately $21 \%$ of the public companies in the Netherlands accounted for the 233 joint ventures.

Figure 1 shows the motives underlying the joint ventures by sector. Chemical and petrochemical companies are strongly represented in the sample; companies in this sector of industry formed nearly one-third of the total number of joint ventures. The most common motive was market development, followed by technology and efficiency.

Table 1 presents the distribution by location of joint ventures and nationality of the partners. Approximately a quarter of the joint ventures are based in the Netherlands. Most of the joint ventures are established in the country of one of the partners. This is due to the fact that the Netherlands is a small country with a long international trading history.

\section{B. Methodology}

The analysis of the value effect of joint ventures includes only the

1. Financial institutions were not included in the sample because they are not comparable to other sectors in that they are regulated by the Dutch Central Bank. Moreover their annual accounts differ strongly from those of other companies. 
abnormal part of the market reaction in respect to the parent company share price. ${ }^{2}$ The expected returns on the relevant days were estimated by means of the market model approach. The abnormal return $\left(A R_{i, t}\right)$ of a share $i$ at time $t$ is calculated as follows: ${ }^{3}$

$$
A R_{i, t}=R_{i, t}-\left(a_{i}+b_{i} R_{m, t}\right)
$$

where $R_{i, t}$ is the effective return of share $i$ at time $t, a_{i}$ a constant term of share $i, b_{i}$ is the systematic risk of share $i, R_{m, t}$ is the he market return at time $t$ and $a_{i}+b_{i} R_{m, t}$ is the expected return on share $i$ according to the estimated market model.

To measure the full effect of the announcement, the abnormal return $\left(A R_{i, t}\right)$ of the announcement day and the following day were computed and averaged for all sample companies to obtain the cumulative abnormal return (CAR). The standard deviation of the abnormal return of each share in the sample was estimated through observations made during the estimation period (from 200 to 51 days before the announcement). A t-test was used to determine whether the market reaction on and around the day of the announcement significantly deviates from zero (Brown and Warner [1985]). In addition to CAR, the standardized cumulative abnormal return, or SCAR, was included in the analysis. $^{4}$

To gain further insight into why some reactions are negative while others are positive, we accomplish a regression analysis of the CARs using several different variables. Joint ventures and similar capital

2. In order to verify the stability of the estimated market model, Cannella and Hambrick (1993), three alternative performance criteria have been calculated. They are based on the following: (i) Returns corrected for the market. This method comprises the effective return minus the market return, i.e. without estimating the parameters alpha and beta as in performance criteria (1). (ii) Returns corrected for the average. The return is calculated by subtracting the average return of the share in the estimation period from the effective return. (iii) Effective return. The uncorrected return during the announcement. In addition a verification analysis was also performed based on the 'buy and hold' investment strategy. The extraordinary buy and hold return is also based on the market model; however a composite return is the starting point. The results of the alternative methodologies are similar to those reported in the paper.

3. The parameters $a$ and $b$ were estimated using the least square method, based on observations made during the estimation period. The estimation period runs from 200 to 51 days before the announcement day.

4. Unlike CAR, SCAR is normally distributed for each hypothesis (Strong [1992]). 
investments come forth out of the strategy process of firms; e.g.; Copeland (1995). To explain wealth effects of joint ventures, the dimensions that characterize the strategy should be able to explain the observed variance in CAR.

In the decision-making process involved in formulating a joint venture, three strategy dimensions are distinguished: Strategy Content, Strategy Context and Strategy Control. The strategy content of a joint venture concerns the characteristics of the actual strategy itself. Two characteristics of the strategy content are taken into account: the functional motive underlying a joint venture and the degree of diversification realized by the joint venture. Research into joint venture motivations distinguishes motives stemming from market and technology developments; e.g., Koh and Venkatraman (1991) and Das, Sen and Sengupta (1998). These studies show that alliances primarily motivated by technological issues have a more positive impact on the market value of companies than marketing-oriented joint ventures. These studies did not examine efficiency improvement as a motive. The influence of the degree of diversification of the joint venture is not clear. Depending on the theoretical concepts used, diversification influences the value effect of the alliance either positively (Balakrishnan and Koza [1993]) or negatively (Koh and Venkatraman [1991]). To explain the value effects, the authors respectively applied the transaction cost approach and the strategic behavior perspective.

The strategy context defines the decision-making parameters of the environment. Important elements are partner selection, the nationalities involved, and the associated cultural differences. Mohanram and Nanda (1998) and Koh and Venkatraman (1991) found that companies gain more excess returns if they enter into an alliance with a larger partner. The relative size of the partner appears to be a relevant factor in establishing the value potential of a joint venture. Closely examined in the relationship between partners is the effect of the relatedness ${ }^{5}$ of the partners, i.e., the degree of similarity between their activities. Research conducted by Koh and Venkatraman (1991) and Balakrishnan and Koza (1993) produced conflicting conclusions and, as a consequence, have been a source of debate. Studies which investigated the nationality of chosen partners and its impact on joint venture wealth effects yielded few results so far. The studies focused on American companies (Lee and

5. To avoid confusion the term relatedness is used to characterize similarities between parents and the term diversification is reserved to characterize similarities between the activities of the joint venture and the parent that is under investigation. 
TABLE 2. Overview of the Results Found in the Literature

\begin{tabular}{llcl}
\hline Dimension & Variable & Expectation & Authors \\
\hline Content & Technology & + & Das, Sen and Sengupta (1998) Chan, \\
& Marketing & - & Kensinger, Keown and Martin (1997) \\
& Efficiency & \pm & \\
& Diversification & \pm & Koh and Venkatraman (1991) \\
& & & Mohanram and Nanda (1998) \\
Context & Partner relatedness & \pm & Koh and Venkatraman (1991) \\
& & & Balakrishnan and Koza (1993) \\
& Individualism & - & Datta and Puia (1995) \\
& & & Bleeke and Ernst (1993) \\
& Relative size & + & Mohanram and Nanda (1998) \\
& & & Koh and Venkatraman (1991) \\
& & & McConnel and Nantell (1985) \\
Control & Majority & + & Bleeke and Ernst (1993) \\
& & & Copeland et al. (1995) \\
& Equality & + & \\
& Minority & - & \\
\hline
\end{tabular}

Wyatt [1990] and Borde, Whyte, Wiant and Hoffman [1998]) and produced contradictory lists of countries and economic regions where joint ventures were either successful or unsuccessful in generating shareholder value.

Following Datta and Puia (1995) and Kogut and Singh (1988), for the purposes of this study cultural difference, measured by the variable individualism, was selected as the distinguishing indicator of nationality, since it was also used in qualitative studies by Bleeke and Ernst (1993) and others. As a rule, these studies show that cultural differences can lead to management problems. We therefore expected this dimension to have a negative effect.

Finally, Strategic control is the extent to which an enterprise can exert influence on the development of the joint venture. The ownership structure is a clear manifestation of the degree of influence that a company can exert on the joint venture. The distribution of control within joint ventures is discussed in depth in qualitative studies; e.g., Bleeke and Ernst (1993). Koh and Venkatraman (1991) found that one party having more control within an alliance had a positive effect. In contrast, Bleeke and Ernst (1993) argue that an equal balance of control makes it easier to manage a joint venture and consequently increases the probability of success. None of the studies in table 2 developed an 
TABLE 3. Test Results of CAR and SCAR

\begin{tabular}{lll}
\hline period $t(i, j)$ & CAR $(\%)$ & SCAR \\
\hline$(-1,0)$ & $0.40^{* * * *}$ & $3.50 * * *$ \\
$(-1,1)$ & $0.39^{* * *}$ & $3.15^{* * *}$ \\
$(-2,2)$ & $0.39^{* *}$ & $2.15^{* *}$ \\
\hline
\end{tabular}

Note: The table shows the CAR and SCAR for various event windows for a sample of 233 joint venture announcements by Dutch public companies in the period 1987 to 1998 . $* * * p \leq 0.01$ and $* * 0.01<p \leq 0.05$.

integral model to determine the conditions under which a joint venture creates value.

\section{Results}

\section{A. Results of the Event Study}

Average CAR is positive but there is substantial variance, with $57 \%$ of joint ventures associated with positive share price impacts, and $43 \%$ negative. Table 3 provides the results obtained by testing the CAR and SCAR of the 233 joint venture announcements. Over the two-day testing period positive market reactions were found with a significance level of 0.01 for both performance criteria (CAR and SCAR). The CAR is equal to $0.40 \%$. According to CAR, the reactions to joint ventures were both strongly positive ( $1.77 \%$ on average) and negative ( $-1.34 \%$ on average).

To gain further insight into why some reactions are negative while others are positive, we accomplish a regression analysis of the CARs using a strategic explanation model.

\section{B. Impact of the joint venture strategy on CAR}

None of the American studies attempted to develop an integrated model that reveals the dynamics among the strategic factors and the value effects of the joint ventures. The distribution of the factors according to strategic dimensions is addressed above in section II. Investor's interpretation of the strategy content, the context in which this strategy must function, and the extent of the company's control over the implementation of the strategic option determine how much shareholder 
value is generated. The variables investment climate $\left(\right.$ risk-free rate $\left.{ }^{6}\right)$ and industry were included in the analysis as control variables to ensure that they did not have any impact on the research results.

\section{Joint venture strategy}

This section describes the variables used to identify factors that influence the shareholder wealth effects. Each strategic dimension is discussed in terms of what factors were examined and how the variables were examined and calculated. In the regression analysis, the CAR is the dependent variable for the following variables:

$$
\begin{gathered}
C A R_{j}=b_{0}+b_{1}\left(\begin{array}{l}
\text { Technology } \\
\text { Dummy }
\end{array}\right)_{j}+b_{2}\left(\begin{array}{l}
\text { Efficiency } \\
\text { Dummy }
\end{array}\right)_{j} \\
+b_{3}(\text { Diversification })_{j}+b_{4}(\text { Individualism })_{j} \\
+b_{5}(\text { RelSize })_{j}+b_{6}\left(\begin{array}{l}
\text { Majority } \\
\text { Dummy }
\end{array}\right)_{j}+b_{7}\left(\begin{array}{l}
\text { Minority } \\
\text { Dummy }
\end{array}\right)_{j} \\
+b_{8}\left(\begin{array}{l}
\text { Risk-free } \\
\text { Rate }
\end{array}\right)_{j}+b_{9}\left(\begin{array}{l}
\text { Industry } \\
\text { Dummy }
\end{array}\right)+e_{j}
\end{gathered}
$$

where $e_{j} \sim N\left(0, \sigma^{2}\right)$. An explanation of the independent variables of the model follows below:

\section{Strategy Content}

Three dichotomous variables are used to test the impact on the parent company of the underlying motive of the joint venture. The value of the dichotomous variable is 1 if there is a distinguishable motive, otherwise it is 0 . The dummy variables are technology, in the case of a technology development joint venture; marketing, for a market development joint venture; and efficiency, for an efficiency-driven joint venture.

The diversification variable represents the relatedness between the activities of the parent company and those of the joint venture. The

6. In accordance to economic theory, when the risk free rate lowers, so does the cost of capital. With the cost of capital lower it is more attractive for companies to invest. So the risk free rate is a proxy of the investment climate. This control variable helps in identifying over-or undervaluation of the venture due to the economic situation at that particular time. 
relatedness is the difference between the primary three-digit US-SIC number for the parent company ${ }^{7}$ and the joint venture. ${ }^{8}$ The relatedness is divided by 899 , the maximum possible distance used by Balakrishnan and Koza (1993) in their research.

\section{Strategy Context}

The relative size of the partner is calculated by dividing the number of staff the partner employs by the number of staff working for the company whose shares are analyzed. ${ }^{9}$

In discussing the success and failure of cooperative agreements, cultural differences are often used as a reason for failure (Bleeke and Ernst; 1993). Franke, Hofstede and Bond (1991) argue that differences in cultural values, rather than in material and structural conditions, are ultimate determinants of human organization and behavior, and thus economic growth. In their long term study they find empirical support for their thesis. From the proxies used to characterize cultural distance, it became clear that the cultural dimension Individualism had the most explanatory power in explaining economic growth. The dimension of individualism is a criterion for the way in which an individual views his or her relationship with the rest of the collective ${ }^{10}$. Frank, Hofstede and Bond (1991) constructed scores on this dimension based on most major countries. Datta and Puia (1995), Kogut and Singh (1988), Erramilli (1991) and Shane (1992) used these bipolar scores to investigate cultural distance. This study used these scores in calculating cultural distance measured by the individualism dimension. The variable Individualism is calculated by:

$$
\text { Individualism }=\frac{\left(I_{j}-I N L\right)^{2}}{V},
$$

where $I_{j}$ is an index-score on the individualism index of the country of origin of the partner, INL is the index-score of the individualism index of the Netherlands and $V$ is the variance of individualism scores of all countries.

7. Source: Worldscope.

8. Source: KPMG Dealwatch.

9. Das el al. (1998) also used this proxy for the partners in the joint venture.

10. Also used in Hofstede (1980). 


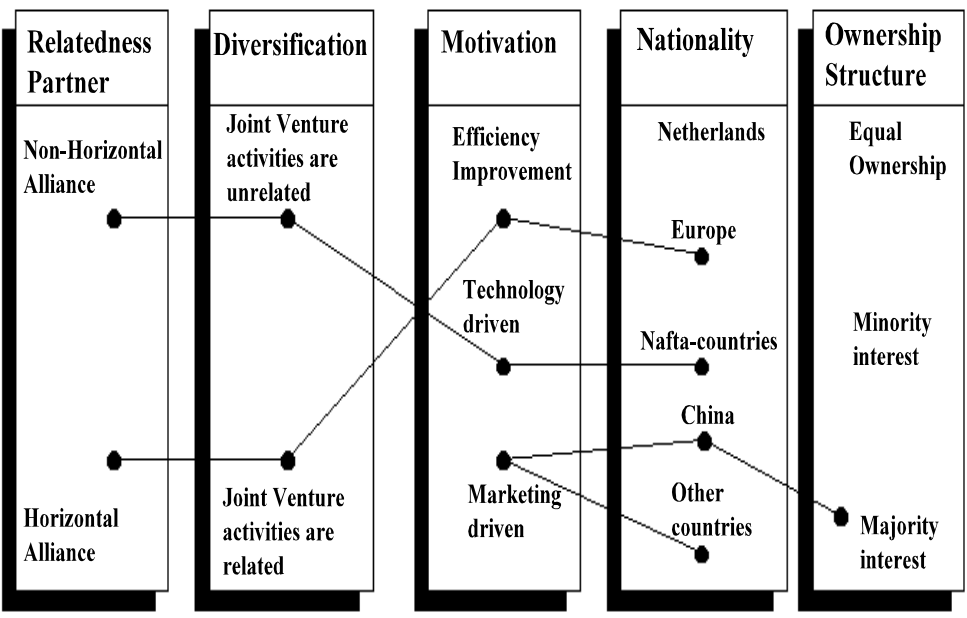

FIGURE 2.-Autonomous Relationships

\section{Strategy Control}

The ownership structure within the joint venture is represented by three dummy variables. Three structures are possible: the company can have a majority, a minority or an equal distribution of shares in the joint venture. It is assumed that the ownership structure correlates with the degree of control in the joint venture. The dummy variables take the value of one if the firm has that particular ownership structure and the value of zero, otherwise.

\section{Control variables}

In order to prevent investment climate and industry specific factors to influence the overall results of this study we control for them by using control variables in the regression. To measure the effect of investment climate the variable risk-free rate $\left(R_{f}\right)$ is added to the model. This return is equal to the yield of ten-year government bonds.

The study also takes industry effects into account. Based on SIC number, ${ }^{11}$ the companies in the sample are classified into the following sectors of industry: construction, food, publishing, (petro) chemical, steel and rubber, electronics, logistics, and services. Industry effects are

\footnotetext{
11. Standard industry classifications.
} 
TABLE 4. Estimated Functions and Test Results

\begin{tabular}{lllll}
\hline & & & SCAR & CAR \\
\hline \multirow{2}{*}{ Strategy } & Variable & $\begin{array}{l}\text { Expected } \\
\text { Result }\end{array}$ & Result & Result \\
\hline \multirow{4}{*}{ Content } & Constant & & $1.357^{* * *}$ & $2.492^{* * *}$ \\
& Technology & + & $0.832^{* * *}$ & $1.584^{* * *}$ \\
& Efficiency & \pm & $0.843^{* * *}$ & $1.570^{* * *}$ \\
Context & Diversification & \pm & $-2.877^{* * *}$ & $-5.180^{* * *}$ \\
& Inividualism & - & $0.287^{* *}$ & $0.433^{* *}$ \\
Control & Rel. Size & + & $0.057^{* * *}$ & $0.101^{* * *}$ \\
Control variable & Majority & + & $0.975^{* * *}$ & $2.134^{* * *}$ \\
& $R_{f}$ & & $-0.244^{* * *}$ & $-0.478^{* *}$ \\
& Publishers & & $2.685^{*}$ & $5.245^{*}$ \\
\hline$R^{2}$ & & & 0.492 & 0.492 \\
Adj. $R^{2}$ & & & 0.399 & 0.399 \\
$F$-value & & & $5.530^{* * *}$ & $5.303 * * *$ \\
$N$ & & & 110 & 110 \\
\hline
\end{tabular}

Note: This table shows the results of the estimated functions of the cumulative abnormal returns of a sample of 110 joint venture announcements of Dutch public companies in the period 1987 till 1998. $* * * p \leq 0.01, * * 0.01<p \leq 0.05$ and $* 0.05<p \leq 0.10$.

measured using dummy variables which take the value of one if the firm is in that particular industry otherwise zero.

\section{Autonomous relationships}

Figure 2 shows the autonomous relationships uncovered by the study. Technology joint ventures are mostly initiated between non-horizontal partners in NAFTA territory. Efficiency driven joint ventures are often between horizontal partners within the E.U. region. Marketing driven joint ventures are frequently setup in emerging markets where for China the Dutch firms mostly have a majority stake. In China it is still obligatory to form joint ventures; the Chinese government prevents foreign firms to have full control of Chinese subsidiaries.

\section{Estimated functions and testing results}

A regression analysis was conducted to measure the explanatory power of the synthesis model (2). There appeared to be little difference 
between the results of the various performance criteria. The results presented here are based on the CAR and SCAR performance criteria. Only the significant effects are shown in table 4 . The results reveal that all the given strategic factors help to explain the performance of joint ventures. The model that incorporates the strategic dimensions provides a stronger, more substantial explanation for the variation in the cumulative abnormal returns than the control variables alone.

The contribution of the control variables on $R^{2}$ of the estimated functions is $5 \%$ on average. The variables from the synthesis model appear to be relevant to the explanation of the shareholder wealth effects of joint ventures. The estimated regressions are checked for multicollinearity using VIF-statistics. The few correlations between the explanatory variables are not significant, as the value of VIF-statistics of approximately 1 is low.

\section{Summary and conclusions}

On average the joint ventures that Dutch companies entered in the period 1987-98 generated value. Notably, companies tended to enter joint ventures when their performance was less than adequate. The statistics show that on average the company performance was below the average stock market performance in the years before the joint venture announcement. This means that we now have an explanation for the negative relationship between return and joint venture activities observed by Berg and Friedman (1977). Our results demonstrate that companies were already performing poorly prior to deciding to enter a joint venture and that joint venture decisions were a reaction to the poor results rather than their cause. In bad times, when shareholder value is deteriorating, joint ventures can provide rays of hope. In this study, the intensity of these rays is expressed through characteristics of the strategy dimensions: Strategy Content, Strategy Context and Strategy Control.

\section{A. Strategy Content}

The substantive function that a joint venture fulfils for a company is an important component in the evaluation of a joint venture. As shown by the results of Koh and Venkatraman (1991) for joint ventures and Das, Sen and Sengupta (1998) for alliances without share participation, technology development joint ventures have a higher impact on a 
company's market value than market development joint ventures. The average value created by efficiency-driven joint ventures lies somewhere in between.

The less the activities of the joint venture are related with those of the parent company, the less enthusiastic the investor reacts. In order to create shareholder value it is essential for a company to utilize its core competencies. With an increasing distance between the new activities comes increasing difficulty in effectively deploying the company's competencies. Moreover, there is less potential for the joint venture to affect the core activities and, since most of the corporate value stems from the core activities, a distant joint venture is less likely to be able to generate significant impact. It seems that there is an optimal degree of diversification for joint venture contracts. Investors are usually not in favor of companies using joint ventures for reasons of strong diversification.

\section{B. Strategy Context}

The American studies show the various impacts of partner nationality. In our study we found that joint venture partners that scored high on individualism have a positive impact on value creation. As no other economic variables appear to make any contribution, it is plausible that investor reactions are partly based on the perception of the economic power of the partner's country of origin and business location.

Research shows that the relatedness of the partner's activities is of less importance in determining the value generated by a joint venture. Investors focus on the activities of the joint venture. However, the analysis reveals that horizontal partners are usually selected for horizontal joint ventures and vice versa. Neither conventional testing of differences in means nor regression analysis uncovered any impact on value creation by joint ventures. The overlap in the partners' activities is the result, rather than the cause, of the joint venture and its objective. The debate conducted in the literature on the impact of overlapping strategic activities appears to be irrelevant in our research.

Partner size has a strong effect on the performance of a joint venture. The variable is highly significant and positive for all performance criteria. In their qualitative study, Bleeke and Ernst (1993) concluded that a stronger partner is a prerequisite for a successful joint venture. The regression results and the univariate tests support this theory. The results of this study show that venturing with relative large partners result in higher wealth effects. For smaller firms the joint venture can 
underline the value of its business proposition through the acceptance of larger partners. The initial impact of venturing with smaller partners doesn't seem to be very high. When there is much excitement surrounding a joint venture with a smaller partner, this can be attributed to the promise of technology/ innovation.

\section{Strategy Control}

Joint venture announcements with an unequal partner shares gain higher wealth effects then with an equal (50/50) partner share. From the data observed, it seems that joint ventures with an equal share distribution receive a negative premium. Minority partner shares receive on average positive wealth effects, but report less strong significance in the multivariate regression tests. The valuation of a joint venture is especially positive for companies that have a majority interest. A majority interest gives a company a dominant position in the collaboration, ensuring that the company has more control over the achievement of the objectives of the joint venture. The results contradict the prevailing paradigms that assert the importance of equality in cooperative alliances. Bleeke and Ernst (1993), Harrigan (1988) and Copeland et al. (1995) underlined the importance of equality in the ownership structure. If shareholder value is the target, then equality within an alliance is not essential. It is more important that the ratios should be fair and bear a connection to the value of the resources (knowledge, capital and other assets) in which each party invests in the joint venture. It appears that the equal distribution of share capital at any cost is not appreciated by investors and has a negative impact on market value. Furthermore, investors have more confidence in joint ventures with one captain than those with two.

The synthesis of the aggregate strategic dimensions explains a great deal of the share price reaction. Clearly, investors respond consistently enough to joint venture announcements to justify the development of an analytical model based on these factors.

\section{References}

Balakrishnan, S. and Koza, M.P. 1993. Information asymmetry, adverse selection and joint-ventures. Journal of Economic Behavior and Organization 20: 99-117.

Berg, S. and Friedman P. 1977. Joint ventures, competition and technological complementaries. Southern Economic Journal 43: 1330-1337.

Bleeke, J. and Ernst D. 1993. Collaborating to Compete. John Wiley \& Sons, 
Inc: New York.

Borde, S.F.; Whyte, A.M.; Wiant, K.J; and Hoffman L.L. 1998. New evidence on factors that influence the wealth of international joint ventures. Journal of Multinational Financial Management 8: 63-77.

Brown, S.J. and Warner, J.B. 1985. Using daily stock returns: The case of event studies. Journal of Financial Economics 14: 3-31.

Cannella Jr, A.A. and Hambrick, D.C. 1993. Effects of executive departures on the performance of acquired firms. Strategic Management Journal 14: $137-152$.

Chan, S.H.; Kensinger, J.W.; Keown, A.J; and Martin J.D. 1997. Do strategic alliances create value? Journal of Financial Economics 46: 199-221.

Copeland, T.; Koller, T.; and Murrin J. 1995. Valuation: Measuring and managing the value of companies. John Wiley \& Sons, Inc: New York.

Das, S.; Sen, P. K.; and Sengupta, S. 1998. Impact of strategic alliances on firm valuation. Academy of Management Journal 41: 27-41.

Datta, D.K. and Puia G. 1995. Cross-border acquisitions: an examination of the influence of relatedness and cultural fit on shareholder value creation in U.S. acquiring firms. Management International Review 35: 337-359.

Erramilli, M.K. 1991. The experience factor in foreign market entry behavior of service firms. Journal of International Business Studies 22: 479-501.

Fama, E.F; Fisher, L.; Jensen, M.C.; and Roll, R. 1969. The adjustment of stock prices to new information. International Economic Review 10: 1-21.

Franke, R.H; Hofstede, G.; and Bond, H. 1991. Cultural roots of economic performance: A research note. Strategic Management Journal 12: 165-173.

Harrigan, K.R. 1988. Joint ventures and competitive strategy. Strategic Management Journal 9: 141-158.

Kogut, B. and Singh, H. 1988. The effect of national culture on the choice of entry mode. Journal of International Business Studies 19: 411-432.

Koh, J. and Venkatraman, N. 1991. Joint venture formations and stock market reactions: An assessment in the information technology sector. Academy of Management Journal 34: 869-892.

Lee, I. and Wyatt S.B. 1990. The effects of international joint ventures on shareholder wealth. The Financial Review 25: 641-649.

McConnell, J.J and Nantell, T.J. 1985. Corporate combinations and common stock returns: The case of joint ventures. The Journal of Finance 40: 519-536.

Mohanram, P. and Nanda, A. 1998. When do joint ventures create value? Working paper. Harvard Business Studies.

Shane, S.A. 1992. The effects of cultural differences in perceptions of transaction costs on national differences in the presence for licencing. Management International Review 32: 295-311.

Strong, N. 1992. Modeling abnormal returns: A review article. Journal of Business Finance and Accounting 19: 533-553. 